\title{
ENTRE BOLONHA E PORTUGAL: A EXPERIÊNCIA POLÍTICA DO CONCEITO DE IURISDICTIO (SÉCULOS XII E XIII)*
}

\section{BETWEEN BOLOGNA AND PORTUGAL: THE POLITICAL EXPERIENCE OF THE CONCEPT OF IURISDICTIO (XII ${ }^{\mathrm{TH}}$ AND XIII ${ }^{\mathrm{TH}}$ CENTURIES)}

\author{
Maria Filomena Coelho**
}

\begin{abstract}
RESUMO
Dizer o direito (iurisdictio) era a concretitude da política na Idade Média. A importância dessa ação para o exercício do poder pressupunha diversos níveis, entre eles o que se classificaria hoje como teórico, pelo qual se conhece a reflexão dos principais juristas de então. Entre os séculos XII e XIII, Bolonha foi o centro de referência para os estudos jurídicos e por lá passaram importantes nomes ligados ao nascente reino de Portugal. Silvestre Godinho e Vicente Hispano são algumas das referências famosas que dão identidade a essas trocas no âmbito da cultura jurídica. Neste artigo pretende-se apresentar alguns problemas de pesquisa em torno do entrelaçamento do conceito de iurisdictio que emanava de Bolonha, entre os séculos XII e XIII, e as maneiras como era apropriado/experimentado no cenário político português.
\end{abstract}

\section{PALAVRAS-CHAVE}

Jurisdição medieval. Estudos de Bolonha. Portugal medieval.

\begin{abstract}
The act of saying the law (iurisdictio) was the political concreteness in the Middle Ages. The importance of that act in the exercise of power attains some levels as such the theoretical from which we know the thought of the main jurists of that time. Between the XII ${ }^{\text {th }}$ and the XIII ${ }^{\text {th }}$ centuries, Bologna was the center of reference for law studies to which were connected some of the most important names of the recently born kingdom of Portugal. Silvestre Godinho and Vicentius Hispanus are some of the most famous ones that represent those exchanges in the juridical culture domain. In this article we intend to present some problems of research about the intertwining of the concept of iurisdictio issued from Bologna and how it was appropriated/experienced in the Portuguese political scenario.
\end{abstract}

\section{KEYWORDS}

Medieval jurisdiction. Bologna studium. Medieval Portugal.

\footnotetext{
* Este artigo é o resultado parcial do projeto de pesquisa “Jurisdição e experiência política: a construção da aristocracia cristã em Portugal (séculos XII e XIII)”, desenvolvido como pós-doutorado na Scuola de Giurisprudenza da Università degli Studi di Firenze, entre julho de 2015 e fevereiro de 2016, com financiamento da Capes, na qualidade de Estágio Sênior. Aproveito para agradecer a generosidade com que os professores Paolo Cappellini, supervisor do estágio, e Pietro Costa me receberam e se dispuseram a discutir meu trabalho. Sou também grata ao Centro di Studi per la Storia del Pensiero Giuridico pela acolhida institucional.

** Professora Adjunta 4, de História Medieval, do Departamento de História e do Programa de Pós-Graduação em História da Universidade de Brasília (Brasília, DF, Brasil); Doutora em História Medieval pela Universidad Complutense de Madrid (1993). Realizou pós-doutorado em História do Direito e das Instituições, pela Universidade Nova de Lisboa (2003), e em Storia del Pensiero Giuridico, pela Università degli Studi di Firenzi (2016). E-mail: filocoelho@hotmail.com
} 


\section{INTRODUÇÃO}

Propor uma reflexão sobre a experiência política do conceito iurisdictio, entre os séculos XII e XIII, significa recorrer aos registros que a história legou e cuja autoria, frequentemente, atribui-se a juristas. Embora os textos que hoje classificaríamos como doutrinais sejam peças que também permitem decodificar a experiência do autor - uma vez que a elaboração teórica não se dissocia da vida -, pretende-se, neste artigo, recorrer a registros documentais que possibilitem compreender como esses juristas, por meio de uma linguagem especializada, estruturavam e redimensionavam os cenários políticos, nos quais eram muitas vezes atores ${ }^{1}$.

Não se trata de pôr à prova a coerência dos juristas, entre aquilo que pensaram e escreveram num plano teórico e aquilo a que as circunstâncias políticas os teriam obrigado. Tal operação, para além de reduzir o problema a um esquema artificial inútil, leva a conclusões que oscilam entre a debilidade de caráter do autor - que pensa de uma forma, mas age de outra - e o sentimento de inadequação das ideias à época em que foram pensadas. Em ambos os casos, manifesta-se a dificuldade do historiador em entrelaçar teoria e prática no tempo, diferentemente do que experimentaram os atores históricos. Ao contrário da historiografia, que se inclina amiúde por interpretações que alçam o plano teórico a um nível ideal, que a prática teima em desvirtuar, os juristas medievais engajados na ação política trançavam os dois níveis num permanente jogo especular, no qual é possível descortinar a intensidade com que a elaboração teórica reatualizava a ação e a ação inspirava a elaboração teórica.

A circunscrição dos conceitos era, sobretudo, estabelecida no confronto político, o que submetia as definições a permanentes tensões e exigia que elas fossem suficientemente elásticas para suportar o espírito casuístico que presidia o ato de “dizer o direito” (ius dicere). Os alicerces abstratos que fundavam os conceitos eram vivificados pela experiência que, aos olhos de hoje, se reduz a uma aparência de instabilidade institucional e de contradições jurídicas. Tampouco se deve pensar que essa casuística fosse sinônimo de anarquia e de caos institucional, arrastando a política ao sabor dos episódios e das circunstâncias. De fato, o peso que a experiência assumia na política exigia a formulação de regras, normas, estatutos e ordenamentos, e o jurista era o intérprete mais adequado para fazer a mediação entre a história e os valores da sociedade (GROSSI, 2014, p. 27).

Em termos concretos, neste artigo deseja-se propor algumas reflexões e problemas em torno da formulação do conceito iurisdictio e de seu redimensionamento na casuística política,

\footnotetext{
${ }^{1}$ Sobre a estreita relação entre linguagem e conceito, ver a obra incontornável sobre iurisdictio na Idade Média, de Pietro Costa: "[...] i concetti non sono declinazioni dello Spirito, ma si formano e si trasformano entro un tessuto linguístico che deve essere ricostruito nelle sue interne relazioni e trasformazioni [...]” (COSTA, 2002, p. LXXXVI).
} 
protagonizados por atores que, ao mesmo tempo, o produziam e o experimentavam. Entre os séculos XII e XIII, destaca-se a atuação de alguns personagens do mundo jurídico que alcançaram grande protagonismo na História de Portugal, nos reinados de Sancho I, Afonso II e Sancho II. Referimo-nos, principalmente, a Vicente Hispano, mas também a Silvestre Godinho, a Julião Pais, a Julião Juliães. Os juristas desse tempo, em sua maioria eclesiásticos, compartilham origens intelectuais identificadas com os chamados Estudos de Bolonha, o que significa dizer que tinham uma formação acadêmica baseada no direito romano, em suas vertentes civil e canônica. Para além daqueles, cuja presença em Bolonha está amplamente comprovada como alunos e professores Silvestre Godinho, Vicente Hispano - há os que, sem nunca lá terem estado, compartilhavam a mesma formação, quer por meio do estudo do Corpus Justinianeu, do Decreto de Graciano e das Decretais, quer pelo aprendizado que eventuais passagens pela cúria papal propiciavam, e onde se respiravam os "ares de Bolonha”.

\section{IURISDICTIO COMO PROBLEMA}

“Dizer o direito” era o ato político mais completo a que se podia aspirar no exercício do poder. Desse ato e das palavras que o nomeiam deriva o conceito de iurisdictio, que manteria grande protagonismo até o final do Antigo Regime, traduzido em romance como jurisdição. Os conflitos jurisdicionais que atravessaram a vida política do ocidente cristão constituem o espetáculo do poder por excelência e pode-se tomá-los como fio condutor para conhecer os fundamentos que davam estabilidade e, ao mesmo tempo, dinamizavam o modelo e as práticas nos quais se assentava a sociedade.

A concorrência entre os poderes que, no plano jurídico, manifestava-se em intermináveis disputas jurisdicionais, revela-se ao historiador numa configuração e geometria complexas, que obrigam a interpretações que ultrapassem os reducionismos das lutas de classes ou do progresso/retrocesso das instituições. Estudos recentes, principalmente dedicados à Idade Moderna e ao Antigo Regime, mostram que, a despeito da tipologia do conflito jurisdicional, a composição social dos bandos enfrentados era extremamente variada, assim como não era linear e previsível o comportamento das instituições ${ }^{2}$. Uma disputa em torno de direitos eclesiásticos que enfrentasse o bispo ao monarca colocava do lado do ordinário pessoas oriundas das diversas ordens sociais e com capacidades econômicas muito variadas, observando-se a mesma configuração do lado do rei. No

\footnotetext{
${ }^{2}$ Com relação à Idade Média, há ainda muito a ser feito. Para o Antigo Regime, ver, por todos, HESPANHA, 1994. O autor tem, ainda, uma extensa e bem conhecida obra, na qual aprofunda questões essenciais a essa temática e, com frequência, ressalta a necessidade de se repensarem as conclusões a que, na matéria, os medievalistas chegam.
} 
que tange ao aspecto institucional, o fato de constituir um embate entre o poder eclesiástico e o monárquico não impedia que a vinculação jurídica dos atores fosse, em ambos os lados, religiosa e laica, e que estes adotassem discursos e estratégias considerados hoje contraditórios, que “debilitariam” a instituição da Igreja ou da coroa ${ }^{3}$.

Entre os séculos XII e XIII, sob a influência da glosa de Bolonha no direito romano, a iurisdictio não era a jurisdição de épocas mais modernas ${ }^{4}$. Não se tratava exatamente dos limites atinentes ao exercício de direitos e liberdades de um corpo, mas - podendo, inclusive, significar isso - a iurisdictio constituía uma peça importante na engrenagem da concepção do poder, ou seja, da autoridade de “dizer o direito”. O próprio verbo “dizer” que se incrusta na palavra remete para uma característica importante do conceito, fundada na longa tradição da justiça romana.

De acordo com Paolo Cappellini, a concepção de direito elaborada em Bolonha desenvolveu-se com base em lógicas que se fraguaram mesmo antes da república romana, quando a esfera mágico-religiosa abrangia o direito (ius), unindo o sagrado e o jurídico ${ }^{5}$. O direito era sacerdotal, pronunciado por um pontífice (aquele que aponta e abre caminhos), que recorria a fórmulas para responder aos problemas que lhe eram apresentados. Portanto, um rito responsório (responsum) oral, com conteúdos originados na cultura, traduzidos e atualizados por magistrados que garantiam a permanente relação entre o direito e a memória dos usos e costumes (mores). Ius dicere era a enunciação aristocrática do direito, a cargo de um grupo de especialistas cuja autoridade advinha de um conhecimento específico.

Saber interpretar as leis significava praticar hermenêutica no próprio étimo, i.e., a capacidade de intermediar mensagens para responder a tensões de contendas, distúrbios antinaturais. O direito aplicava-se como se pertencesse à ordem da imanência, entendido numa dimensão naturalista, pela qual existia sem decisiva interferência externa. Restava ao homem apenas a tarefa de descobri-lo (invenere). Embora na República os pontífices tenham sido substituídos pelos juristas, manteve-se a lógica de entender o direito como responsum, numa perspectiva mais laica e técnica - em linhagem direta do termo grego -, que se estendeu ao longo do Império. Os juristas descobrem - porque existe na natureza - o direito das coisas, o direito que a natureza dita. Para o tema que nos interessa de perto, a tarefa que Justiniano encarregou a Triboniano, no século VI, de compilar aquilo que lhe parecesse mais significativo e útil do

\footnotetext{
${ }^{3}$ Ver, por exemplo, COELHO, 2006.

${ }^{4}$ Paolo Grossi prefere usar a palavra em latim: “[...] o que o ideário medieval exprime como o conceito de iurisdictio, termo latino (e não será o único) que, por sua especificidade destinada a ser irremediavelmente desvirtuada pelo termo correspondente "jurisdição”, vamos deixar na língua original [...]” (GROSSI, 2014, p. 161-162).

${ }^{5}$ As referências e o conteúdo que se seguem nas próximas páginas, atinentes ao direito em Roma e às propostas da escola de Bolonha resultam das notas do curso de Storia del Diritto, ministrado pelo Prof. Paolo Cappellini, na Scuola de Giurisprudenza, da Università degli Studi di Firenze, de setembro a dezembro de 2015.
} 
pensamento jurídico dos antigos romanos, teve como resultado a obra referencial obrigatória, com grande fortuna no ocidente: o Corpus Iuris Civilis ${ }^{6}$. Tratava-se de um monumento à justiça, resultado de uma metodologia que descontextualizou as responsa de alguns antigos jurisconsultos para reconfigurá-las de maneira a oferecer aos magistrados um depósito de saber para referir seus atos de "dizer o direito". Assim, tanto os critérios de seleção dos extratos escolhidos por Triboniano, quanto os objetivos a que se destinavam, desautorizam a considerá-los na perspectiva de códigos, fundados no princípio da totalidade e da completitude, submetendo a circunstância à norma (CRESCENZI, 1992, p. 122-123).

Para os romanos, como já referido, o direito não era um conceito abstrato. O Digesto $^{7}$, um dos famosos livros do Corpus Iuris, ensina que somente se chega à justiça por meio de casos concretos (casuística), no momento em que se encontra (invenere) a solução adequada para determinada situação. Qualquer definição abstrata em direito era perigosa, porque seria arbitrária. O jurista não era um teórico do direito, um elaborador de princípios, mas um intérprete de casos que se apoiava em regras que definiam previamente uma coisa, de forma provisória, como síntese jurisprudencial, e somente o caso concreto podia dar substância ao direito. Esta é uma palavra concreta (fórmula) que somente se realizava na ação do processo, que incluía a importante decisão sobre diante de qual juiz as partes deveriam comparecer. Assim, a legislação continha a própria ação como motor do texto (lex) - sem a qual era palavra morta - e a maneira correta de citá-la. O Corpus Iuris era, enfim, o resultado de uma cultura jurídica oral, ancorada na pragmática da interpretação e no método da “incompletitude da norma”, o que requeria que o jurista, após verificar de modo arrazoado a efetiva falta, viesse a supri-la para superar o problema (CRESCENZI, 1992, p. 122-123).

Quando, no século XI, Matilda de Canossa encomendou a Irnério um trabalho de renovação dos livros legais, este levou a cabo uma reconstrução da obra de Justiniano a partir de vários manuscritos que haviam sobrevivido, operando também, por sua vez, uma seleção. A dispersão da obra ao longo da alta Idade Média deveu-se, talvez, à falta de conexão entre aquilo que se conseguia depreender de seu conteúdo, que exigia erudição e treinamento, e as necessidades do cotidiano (CRESCENZI, 1992, p. 113). O Estudo de Bolonha, do qual Irnério é referência primordial, fundou o método da glosa, ou anotação, que permitia esclarecer as contradições que o

\footnotetext{
${ }^{6}$ Nome pelo qual ficariam conhecidos, desde a segunda metade do século XVI, os excertos selecionados das obras de antigos jurisconsultos romanos, vertidos para códices, que constituíam livros distintos.

${ }^{7}$ Digesto quer dizer ordenação, ou seja, como as coisas estão ordenadas, organizadas. Portanto, longe do significado político que comumente hoje se atribui às palavras ordenação e ordem, com sentido de imposição. Aliás, é naquele mesmo sentido que se deveria entender o grande monumento jurídico português das Ordenações Afonsinas, das Ordenações Manuelinas e até mesmo das Ordenações Filipinas, uma vez que tal concepção jurídica ainda é válida para o século XVII.
} 
texto justinianeu apresentava. Recorre-se ao cânone bíblico exegético que possibilitava resolver as aparentes incongruências, por meio das distinctiones, o que significa que o texto (tal como a divindade) nunca está errado; são os leitores que precisam ser esclarecidos sobre o seu conteúdo. Posteriormente, Acúrsio, que no século XIII produziu a glosa mais completa (Magna), entendia a interpretatio como ato essencial para adaptar o conteúdo do texto legal e fazê-lo funcionar, acrescentando e estendendo-o a outros casos. Fazer interpolações e acrescentos aos textos originais, bem como realizar supressões, tinham por objetivo afirmar e promover uma ideia, ou proceder à tal adaptação que Acúrsio defendia. De resto, essa era uma prática imemorial no campo da justiça e que garantia a atualização da tradição.

Irnério foi o primeiro a recuperar o termo iurisdictio do léxico jurídico romano para resolver controvérsias, esclarecendo a casuística por meio do direito, e a defini-lo como um poder vinculado à necessidade de dizer (pronunciar) o direito e de estabelecer equidade (IRNERIO, 1896) ${ }^{8}$. Para tanto, entendia-se fundamental que aquele que julgava tivesse autonomia em relação aos que eram julgados, sintetizando uma série de elementos inseparáveis: o principal, como esclarece Irnério, é a aequitas (equidade), a essência da justiça, princípio divino de ordenação da natureza como ordem imanente das coisas, e que somente o juiz devidamente preparado e autorizado pode tentar alcançar, por meio da capacidade da interpretatio. Esta permite identificar as injustiças e fazer a mediação entre a norma e os fatos, no ato da iurisdictio, que se opera no tempo e no lugar em que se corrigem as injustiças e se restaura a equidade (GROSSI, 2014, p. 216-218). No momento em que "diz o direito", o juiz recompõe a diversidade dos fatos na unidade da origem, restaurando a convenientia (convergência) entre as partes ou as coisas. Para Azzo, no século XIII, iurisdictio funciona como meio entre aequitas e condere legem, possibilitando conduzir a cada momento a distinção e precedência entre as normas. É pela declinação latina de iurisdictio que se compreende a experiência do conceito, ou seja, pela forma como "dizer o direito" conecta palavras e coisas.

Como ato de poder, iurisdictio significa apreender, senão mesmo compreender, os sujeitos na sua incontornável historicidade, criaturas apanhadas num mundo de fatos concretos cujo sentido clama por equidade. Os fatos, em suas concretitudes e circunstâncias, carregam em si a equidade, embora oculta (aequitas rudis), que somente poderá ser devidamente desvendada, interpretada, pelas regras jurídicas (aequitas constituta), que atribuirão aos fatos significados vocabulares, com a intenção de afastar o perigo do caos factual. A realidade não aparece como plena e objetiva em si mesma, pois depende do mediador que a qualifica, por meio de instrumentos linguísticos que

\footnotetext{
8 “Iurisdictio est potestas cum necessitate iuris s. redendi equitatisque statuende” (IRNERIO, 1896).
} 
garantem uma interpretação criteriosa. A linguagem constitui-se, então, em validação, em modelo, como fruto de uma lógica cristã medieval, que deduz a realidade de um processo de poder legitimado (COSTA, 2002, p. 221-222). Entretanto, os fatos não perdem importância em sua singularidade histórica, sobretudo, "para dobrar a rigidez do strictum ius", estabelecendo um vínculo estreito entre equidade e realidade. A singularidade dos fatos pode até mesmo levar o juiz à decisão de não aplicar a lei, ou de preencher seus silêncios, justamente para preservar a equidade e a salvação da respublica christiana.

A escola civilista de Bolonha, desde os primeiros glosadores, concebeu a equidade como válvula de segurança e meio dinâmico de adequação e de estabilidade de um modelo que tinha na factualidade a sua pedra angular. Eram os fatos no tempo que ditavam a ratio aequitas, ou seja, a razão de se aplicar uma pena ou até mesmo de tolerar e fechar os olhos diante de um crime para não causar maior dano à sociedade (GROSSI, 2014, p. 261-265). Tais idiossincrasias apontam para uma compreensão dos textos jurídicos distinta de uma simples exegese, que, embora criativa, encarava a seleção que o texto justinianeu havia feito dos antigos jurisconsultos romanos como uma forma onde se vertiam os fatos do tempo presente ${ }^{9}$. No julgamento desses fatos, as referências explícitas aos textos jurídicos eram o resultado de um ato de interpretatio, devidamente apoiado pela ideia de equidade e pelo costume, o que terminava por elevar esses mesmos fatos a fonte de direito ${ }^{10}$. Nesse sentido, é óbvia a importância da experiência para os juristas, não como sintoma oculto aos próprios atores - a ser desvendado pelo historiador -, mas como elemento intrínseco da concepção jurídica, que eles operavam de forma consciente e criativa. O direito fraguava-se na experiência. O conceito, em sua narrativa escrita, estava repleto de história, embora fosse invocado como referência de autoridade, cuja principal virtude se assentava na fixidez e na imutabilidade.

Há ainda outro problema, amiúde subentendido de maneira esquemática: a relação entre o texto e a realidade, com tendência a se concluir ser um o reflexo do outro. Tal como sublinha Pietro Costa, muito mais do que reflexo, as interferências de um no outro provocavam inesgotáveis transformações de compreensão, mediadas pelas operações de seleção e de interpretação e das estratégias adotadas pelos atores no tempo. Embora as definições fossem, ao mesmo tempo, frágeis - porque mutáveis -, eram também duradouras - porque encerravam um significado modelar de

\footnotetext{
${ }^{9}$ Pepone e/ou Irnério, por meio da linguagem "[...] della scienza del diritto e nel suo âmbito la stessa terminologia giuridica non si esauriscono in una funzione descritiva di quei dati, ma li risolvono in prassi e come tale costruiscono l'esperienza giuridica. [...] non descrivono precetti, ma esplicano una funzione precettiva” (COSTA, 2002, p. 115-117). 10 "O direito comum [...] é interpretatio [...] [,] o mundo histórico do direito comum não é nem pode ser a continuação, no âmbito medieval, do antigo direito romano, pois seu conteúdo são os fatos da época medieval que, graças ao costume e à equidade, tornam-se também fonte formal. É por isso que "glosadores" e "comentadores" são substancialmente bem pouco glosadores e comentadores; são menos ainda romanistas, e o direito comum é bem pouco direito romano modernizado" (GROSSI, 2014, p. 279).
} 
aparência eterna. Assim, para o historiador, muito mais profícuo do que dizer o que era iurisdictio, é tentar compreender como essa imagem medieval estruturante do poder político é descrita em sua historicidade (COSTA, 2002, p. XC-XCI, 70, 95), acompanhando de perto as decisões tomadas pelos atores na confluência das ações com os textos.

Ao retomar a definição de Irnério, compreende-se que iurisdictio era um poder. Entre os séculos XII e XIII, ficava cada vez mais claro que esse poder requeria uma capacidade de coerção encarnada numa persona jurídica, cujas capacidades eram medidas pelo quantum coercitivo. Entretanto, a experiência do conceito que ficou registrada mostra, para essa época, oscilações entre uma percepção inicial, que incidia sobre a dimensão jurídico-política, e outra que se afiançará depois, de caráter mais técnico-jurídica. Basicamente, tratava-se de explicitar não apenas uma relação de poder, mas uma relação coercitiva de poder (COSTA, 2002, p. 111-116). O poder (potestas) é mensurável e, quando mencionado em conjunto à iurisdictio, permite compreender o alcance de seu exercício. Na verdade, a palavra iurisdictio sozinha não quer dizer muita coisa. Nos documentos, ela aparece em frases que decantam a experiência e a conectam com outras palavras no contexto - estas sim, significantes ${ }^{11}$.

De tudo o que se disse, pretende-se destacar que iurisdictio não é um nome que se aplica a uma teoria que nasceu e morreu vinculada ao problema dos ordenamentos particulares, mas é uma palavra-chave que nasceu antes mesmo do comum (comune) e que não lhe esteve condicionada. Iurisdictio é uma palavra-chave do léxico político, indica todos os tipos de desigualdade, de relações de poder, associa-se às ideias de coerção e de legitimidade, alimenta-se de conteúdos feudais, interessa ao ordenamento da Igreja e à supremacia do imperador. Em suma, é o símbolo de um complexo sistema político (COSTA, 2002, p. 173-174) ${ }^{12}$.

De acordo com Pietro Costa, são notáveis os deslocamentos observados na história do conceito, entre os séculos XII e XIV, sublinhando movimentos que, partindo de uma necessária relação desigual, precisam e acrescentam-lhe significados que traduzem primeiro uma relação coercitiva, seguida de uma relação politicamente determinada, depois uma relação eficaz, e, por último, a organização da vida associada: regimen, administratio e civitas (COSTA, 2002, p. 124).

A reter como pedra angular do edifício do poder, iurisdictio, essa capacidade de, simultaneamente, "ligar mundos diversos", um ato que é a manifestação dos alicerces: a unidade como essência fundante da sociedade. Iurisdictio é o ato daquele que tem poder para restaurar a

\footnotetext{
11 Para Pietro Costa constata-se, depois de 1300, a necessidade de especificar o tipo de potestas, limitando o jogo sinonímico que antes se estabelecia entre iurisdictio e potestas (COSTA, 2002, p. 119, 124).

${ }^{12}$ Ballein (symballein - o que se joga simultaneamente) é um símbolo, portanto um conjunto, um complexo, um sistema referenciado às relações de mando e obediência, que compõem as estruturas elementares do poder político.
} 
harmonia, “dizendo o direito" das forças que se enfrentam, de maneira a garantir a unidade. A superfície - ou seja, a realidade - é, pela natureza humana, conflituosa, mas se supõe que aqueles que "dizem o direito" conhecem as profundezas e são capazes de identificar o nível de perigo que as disputas em julgamento representam para a unidade. Portanto, não se tratava somente de resolver e sancionar as disputas, pela aplicação "técnica” da lei, mas ainda garantir que a realidade dos interesses particulares e diferentes fosse convenientemente traduzida na perspectiva da unidade. O intuito não era eliminar as diferenças - absolutamente fundantes e necessárias - mas conhecer e garantir as diversas funções de cada membro nessa unidade. A variedade das circunstâncias e da complexa configuração das forças em confronto era imensa, colocando o magistrado diante de variáveis que se multiplicavam e rearranjavam a cada caso em julgamento, sem falar dos casos que se desdobravam por anos a fio, atravessados também esses por dinâmicas que modificavam seguidamente aquilo que se julgava. Como já referido, num cenário real tão vivo e cambiante, fruto das tensões e da concorrência, a afirmação da unidade era pensada e se manifestava por meio de uma linguagem necessariamente plástica e elástica, na fala e nos atos do magistrado.

A iurisdictio, compreendida em toda a sua abrangência, como palavra-chave que plasmava as relações de poder, estendeu-se naturalmente ao vocabulário dos corpos jurídicos ${ }^{13}$. A concepção da unidade representava-se por meio de um corpo, composto por membros, os quais tinham funções específicas e hierarquizadas em termos de importância. Entretanto, o cumprimento da função dos membros dependia da sua autonomia relativa dentro do corpo e, sobretudo, da garantia de que seu espaço de atuação não seria invadido pelos demais. Cada membro era um coletivo de pessoas, uma comunidade organizada, que, por sua vez, se representava como um pequeno corpo dentro do grande corpo, replicando no seu interior as mesmas lógicas jurídicas que se aplicavam à unidade política e social. Mas não se pode esquecer que tal configuração fundava-se numa sociedade concebida de modo hierárquico e assentada nos privilégios das ordens superiores. Iurisdictio, então, assume um lugar fulcral como nexo articulador do exercício de poder a que cada corpo tem direito, em decorrência da importância de sua função social e/ou da posição que circunstancialmente ocupe no palco político, com resultados variáveis. Os direitos são entendidos como essenciais ao cumprimento da função e iurisdictio não será mais, unicamente, “dizer o direito”, mas também "jurisdição": o espaço vital, o lugar de cada corpo, a autonomia, o poder para cumprir a função. Não ocorreu mudança, ou substituição, da iurisdictio pela jurisdição, com conteúdos profundamente

\footnotetext{
13 “A doutrina mais madura irá vincular a iurisdictio somente à comunidade organizada. Os indivíduos podem ser muitos, mas, enquanto estiverem desarticulados, não lhes competirá nenhum poder normativo judicial; esse poder lhes caberá no momento em que se 'habeant in unum corpus', e então será um multiplicar-se de iurisdictiones em correspondência ao multiplicar-se de autonomias; tantas iurisdictiones quantas entidades autônomas [...]” (GROSSI, 2014, p. 245-246).
} 
diferentes. Houve um acréscimo semântico forçado pela própria forma da história. O pano de fundo mantém-se como poder de “dizer o direito”, de dizer a justiça. Se, num primeiro momento, tratavase do poder atribuído diretamente a um magistrado, que refletia uma relação de dependência jurídica e uma capacidade coercitiva, depois trata-se do poder que os corpos coletivos têm de “dizer o seu próprio direito” (regras, normas) com autoridade sobre outros corpos e pessoas, bem como da falta de poder que se traduz na necessidade de se submeter a outros poderes que "dirão o seu direito".

\section{IURISDICTIO COMO PENSAMENTO E EXPERIÊNCIA DO POLITICUS}

As instituições foram construídas, ao mesmo tempo, pelo pensamento e pela experiência. Entre os séculos XII e XIII, são conhecidos alguns juristas que ocuparam importantes ofícios na cúria régia, em Portugal, e aos quais a historiografia atribui grande capacidade de influência - e até mesmo de autoria - na formulação e execução dos atos da monarquia. Eles são parte do processo que institui o poder político dos reis.

A recepção do direito comum romano-canônico nos ordenamentos civis deve ser considerada nas perspectivas de iure e de fato, ao mesmo tempo. Embora os ordenamentos ibéricos, sobretudo a partir do século XIII, pretendessem estabelecer uma hierarquia que privilegiasse o direito do reino em detrimento do direito comum, o fato é que a influência da escola de Bolonha estava a tal ponto incrustada na cultura jurídica que as referências ao Corpus Iuris, bem como às glosas dos grandes mestres bolonheses, eram constantes (GARCÍA Y GARCÍA, 1985, p. 62-63). É também dessa influência que se deduz a maneira como os juristas, entre os séculos XII e XIII, souberam criar um espaço próprio assentado na sua capacidade técnica de oferecer instrumentos que "harmonizavam e uniformizavam procedimentos, práticas, sistemas rituais e simbologias do poder monárquico” (BRANCO, 2002, p. 24). No espírito de Bolonha, harmonizar e uniformizar apontavam para significados que sublinhavam o caráter jurídico plural dessas elaborações. A harmonia e uniformização nos planos teórico e prático, perseguidas como objetivo amplamente declarado, não supunham a eliminação do que hoje chamaríamos “contradições”. Como vimos no tópico anterior, a lógica do poder e da justiça obedecia à dinâmica casuística e, neste sentido, os responsáveis por estruturar o poder tratavam de elaborar instrumentos que oferecessem àqueles que o exerciam um amplo leque de referências e de jurisprudência para atender às mais diversas demandas e necessidades, de forma a munir o governante de um aparato de legitimidade no qual fundamentar as decisões. 
Nessa época, era notável a presença dos juristas no cenário político português em diversos espaços de poder. Embora a corte fosse o lugar mais emblemático, nem todos os juristas que por ali circulavam estavam diretamente vinculados ao rei, podendo ser apenas procuradores de causas em litígio que recorriam à justiça régia. O importante a sublinhar é a existência de um clima favorável à manifestação de uma cultura jurídica que, até meados do século XIII, tinha em Bolonha sua principal referência. Certamente, muitos desses mestres em leis jamais estiveram em Bolonha e, até mesmo, jamais fizeram estudos de alto nível. O título de mestre que se apunha ao nome podia significar que tinham sido alunos e/ou eram mestres numa escola catedral ou que, simplesmente, eram “entendidos em leis” (JORGE et al., 2005, p. 29).

A elaboração de novas estratégias de governo, de acordo com Maria João Branco, era fruto das "elites mais esclarecidas que rodeavam o monarca" e que inspiraram e promoveram importantes novidades políticas (BRANCO, 2009, p. 150-151). Por exemplo, Sancho I, provavelmente influenciado por seus conselheiros e juristas, fez-se presente no território do reino, promulgou medidas de caráter fiscal que restaurassem e/ou alargassem os direitos régios. A mesma influência é identificada, principalmente com mestre Silvestre, em relação às iniciativas legisladoras do início do reinado de Afonso II, que atingem todos os súditos em termos fiscais (BRANCO, 2011, p. 355358). Mas o sentido/acepção da lei (lex) deve ser visto na perspectiva daquela cultura política. Antes de mais, a lei servia para confirmar a tradição, com uma função certificativa e não inovadora. No espírito de Bolonha, e romano, o texto da lei inseria-se na concepção do direito natural, pelo qual os homens não criavam o direito. No máximo, eram capazes de representar o modelo, que era imutável. Portanto, a lei, a norma, a regra, eram critérios de interpretação e, nessa condição essencial, entendidos como um método necessariamente flexível e fluido. A lei, ainda na tradição romana, não era o direito, e fazer leis não era o mesmo que “dizer o direito” (iurisdictio); apenas uma das manifestações deste, um papel menor com relação ao saber jurídico e à jurisprudência prática (GROSSI, 2014, p. XII-XIII). Ao instituir um critério de interpretação (lex), o rei manifestava o direito, “como constatação - seja ela declaratio, additio, correctio, novatio - de algo que existe, que não se cria, mas que se pode apenas declarar, complementar, corrigir, renovar" (GROSSI, 2014, p. 17).

No que se refere ao caso concreto da produção das leis do início do reinado de Afonso II, a história pregressa e egressa de seu conteúdo não autoriza a pensar num projeto de Estado de grande alcance, visto que parece indicar uma correção circunstancial de rumo da administração pública, com o intuito de viabilizar a legitimidade do reinado. Aquilo que em termos de conteúdo se identifica hoje como inovação era interpretado à luz de um direito que antecedia o monarca 
(consuetudo) e pelo qual ele era limitado. A relação dinâmica que se estabelecia entre lex e consuetudo permitia a flexibilização do próprio costume, "em direção a novos movimentos consuetudinários, numa troca perene que garante o devir harmônico do direito como expressão do social” (GROSSI, 2014, p. 109-111). O rei, em seu papel de legislador da coisa pública, nada mais fazia do que plasmar na prática o espírito de retomada do Corpus Iuris, no século XII, que Bernard de Chartres retratava como anões alçados a ombros de gigantes; pedir o suporte aos antigos, mas sem descurar do dever de enxergar mais e melhor com os próprios olhos, para responder adequadamente aos desafios dos “negócios novos” (GROSSI, 2014, p. 199).

A análise que comumente a historiografia faz com relação às “vicissitudes” políticas enfrentadas por Afonso II, no início de seu reinado, permitem uma boa reflexão. A vitória do monarca sobre as forças que se lhe opunham, principalmente nobiliárias, dever-se-ia, sobretudo, às medidas de cunho jurídico e administrativo que adotou, o que lhe permitira levar a cabo um programa de centralização política. Esta estratégia teria sido desenvolvida pelo corpo de juristas que o aconselhava e que constituía o núcleo principal de seu governo. $\mathrm{O}$ fato de que o monarca não gozasse de boa saúde - provavelmente era leproso - teria contribuído para o fortalecimento desse grupo na cúria régia e para a implementação de um modelo de governo baseado nos princípios da lei romana. Portanto, tal posição historiográfica sugere que as propostas inovadoras de governo dever-se-iam muito mais à capacidade intelectual de juristas-eclesiásticos, que se aproveitaram de uma circunstância ideal, do que propriamente à capacidade política de Afonso II $^{14}$.

O corpus de leis apresentado pelo monarca logo no início de seu reinado, em 1211, conhecido como Leis Gerais, constitui a evidência documental à qual recorrem os historiadores para fundar a convicção de que se pretendia assentar os alicerces de um plano ambicioso e inovador: a centralização do poder ${ }^{15}$. Maria João Branco e Hermínia Vilar, em diferentes obras, lembram que o texto que hoje se conhece das Leis Gerais é oriundo de cópias tardias, posteriores ao reinado de Afonso II, mas que a historiografia não parece preocupar-se com o fato, por considerá-las fiéis ao texto original. Um dos manuscritos, do século XIV, é o Livro das Leis e Posturas; outro, do século XV, integra as Ordenações de D. Duarte; e um terceiro faz parte dos Foros de Santarém. Alexandre Herculano preparou uma edição crítica desses manuscritos, tomando como base o do século XIV (BRANCO, 1997, p. 82; VILAR, 2008, p. 83).

\footnotetext{
${ }^{14}$ Esta capacidade dos juristas da cúria acabava por facilitar a manipulação dos reis, como na relação de mestre Vicente com relação a Sancho II. Nas palavras de Hermenegildo Fernandes, Mestre Vicente "seria o homem de Sancho, enquanto não lhe passou pela cabeça que Sancho deveria ser o homem dele” (FERNANDES, 2010, p. 159).

${ }^{15}$ Seguimos a Maria João Branco, que se propõe retomar este topos historiográfico, analisando novamente o texto das Leis Gerais, em seu contexto de produção, para testar a hipótese de que o rei teria "imposto a sua autoridade por meios legais” (BRANCO, 1997, p. 80).
} 
Seguindo os padrões que a disciplina da História impunha no século XIX, Herculano, provavelmente, escolheu o texto vertido no século XIV, por considerá-lo cronologicamente mais próximo do original - portanto, mais autêntico - e por talvez imaginar que teria sido o Livro das Leis e Posturas a servir de base para as posteriores Ordenações de D. Duarte. Entretanto, a lógica que presidia à tradição metodológica das compilações legais da Idade Média era outra. A própria elaboração do Corpus Iuris, como já referido, ensina que o compilador, ao selecionar os trechos de textos jurídicos antigos para compor a "nova” obra legislativa, orienta-se pelos desafios que a realidade de seu tempo coloca, e procura nos antigos respostas adequadas para realizar a justiça. Assim, imaginar que o compilador tivesse - ou devesse ter - respeito pela integridade do texto é uma visão anacrônica que impede compreender a dinâmica que presidia a construção das compilações legais na Idade Média. Nesse sentido, a possibilidade de que aqueles que compuseram o Livro das Leis e Posturas tivessem sobre a mesa os originais das Leis Gerais, de 1211, não significa que eles mantivessem a integralidade do conteúdo, uma vez que o objetivo primordial não era o de fazer uma cópia fiel, mas o de atualizá-lo em outro contexto. A fidelidade ao efeito era maior do que a fidelidade à letra. O preâmbulo das Leis Gerais, recolhido pelos textos posteriores, dá um bom exemplo disso ao apresentar diferenças relativas à manifestação da capacidade de julgar ou de fazer leis por parte do monarca.

Mais importante, porém, são as interpretações contrastantes que a historiografia propõe sobre o que o documento poderia nos fazer entender a respeito das interações jurisdicionais entre o poder régio e o eclesiástico. Para alguns, a redação do texto não é clara, o que ensejaria as discordâncias quanto aos princípios da hierarquia política propostos no enunciado. Maria João Branco sublinha que José Mattoso, por exemplo, ao atribuir a autoria das Leis Gerais a Vicente Hispano, e por entender que este jurista defendia a supremacia do poder régio ante o pontifício, deduz dessa constatação que a lei em questão não poderia colocar a jurisdição da Igreja acima da monárquica (BRANCO, 1997, p. 83-84; VILAR, 2008, p. 104). Ao contrário do que se alega, o texto parece bastante claro na matéria, apesar das variações que apresenta nas duas fontes:

Outrossi estabeleçeo que as sas leys sseiam guardadas e os dereytos da sancta Egreia de Roma Convem a saber que se forem fectas ou estabeleçudas contra eles ou contra a sancta Egreja que nom valham nem tenham.

E estabeleçeo com o conselho dos sobreditos que as sas leis E dos seus socesores siguam os degredos dos apostolligos de rroma $\mathrm{E}$ os dereitos da santa Jgreia scilicet que se forem feitas ou estabellecidas contra eles ou contra a santa Jgreia non valham nem seiam theudas por leis (MATTOSO apud BRANCO, 1997, p. 83-84). 
Apesar das diferentes redações, não resta dúvida de que qualquer lei que prejudique os direitos da Igreja carrega em si um defeito de natura que a transforma em ilegítima, retirando-lhe, portanto, a autoridade; no segundo, explicita-se claramente a obediência ao direito canônico.

As Leis Gerais não pretendiam afirmar o poder absoluto do monarca nem configuravam um ato político destinado a enfraquecer os demais poderes do reino. Ainda de acordo com Maria João Branco, tratava-se de uma definição dos limites dos respectivos direitos, entre os quais, obviamente, encontrava-se o régio. Por meio da lei, consolidava-se por escrito uma realidade na qual o monarca confirma/define exceções e “carrega consigo a nobreza” (BRANCO, 1997, p. 8788). Embora seja difícil conhecer exatamente a dinâmica que presidia a convocação e o funcionamento das reuniões de cúria, seguindo o suposto texto das Leis Gerais, recolhido pelas Ordenações de D. Duarte, D. Afonso II teria buscado apoio nas ordens superiores no início de seu reinado. Estavam presentes: “dom Pedro enleito de Bragaa e todollos outros bispos do regno E dos altos homeens de rrelegiom E de todollos Ricos homeens E cavaleiros seus vasallos” (VILAR, 2008, p. 83-84). Nesse sentido, as Leis Gerais podem ser consideradas como resultado/efeito da reunião.

Não se conhecem manifestações de descontentamento, sobre as Leis Gerais, que se referissem a uma desmedida vontade de centralização ou ao monopólio do poder por parte do rei. Para a mencionada autora, no contexto conflituoso da promulgação das Leis Gerais - "guerra civil, invasão leonesa, o caso das infantas e suas ramificações, disputa com o arcebispo de Braga, crise econômica” - seu impacto foi diminuído (BRANCO, 1997, p. 84). Talvez o objetivo da elaboração desse corpus pudesse ser colocado justamente na perspectiva daquele cenário político, mas não como a frustração de uma vontade soberana impossível de se concretizar, porque se manifestou num momento desfavorável. Tal análise acaba por reduzir a intenção à incompetência do cálculo, ou a uma conclusão anacrônica, recorrente na historiografia, de que tais propostas eram ensaios políticos de centralização, frustrados pelo peso da realidade histórica.

Entretanto, Maria João Branco, em suas reflexões sobre o próprio texto das Leis, sublinha um conteúdo que não podia ser interpretado como desrespeitoso aos direitos dos corpos, atentatório às jurisdições que constituíam o tecido político do reino. Ao contrário, o monarca, como já foi antecipado, reafirmava direitos e jurisdições, tratando de (re)afirmar sua presença e importância na urdidura dessa trama. Assim, havia uma manifestação de grande interesse político naqueles momentos iniciais, cujas intenções podem ser aquilatadas pelo que se diz claramente com relação à função régia, tecidas juntamente às palavras da lei: o rei protege os bons costumes e combate os maus, protege a Igreja do seu reino, protege os seus súditos. 
No que tange à aparente falta de homogeneidade do texto das Leis Gerais, que tanto incomoda a historiografia, deve-se entender que essas compilações seguiam o espírito de responsum que a justiça deveria assumir ante a desordem e a injustiça. Portanto, a pretensão era de ordenar (escrever uma ordenação, um digesto) uma casuística, com uma organização interna que nossa lógica contemporânea tem muita dificuldade de apreender. Nesse sentido, a aparente "falta de homogeneidade” não pode atestar, por exemplo, a existência de expurgos ou interpolações, o que teria perturbado a harmonia do texto. Provavelmente, o texto sofreu mesmo intervenções, mas isso não significa que o original fosse estruturado de acordo com uma lógica similar à de nossas expectativas contemporâneas de coerência jurídica. O Digesto, padrão de referência dessas obras, apresenta também uma organização e um conteúdo que hoje consideraríamos anárquicos e incoerentes. Entretanto, a forma resultava da função: servir como depósito de respostas às mais diversas situações de conflito e incerteza, o que explica seu caráter aberto e conteúdos contrastantes (contraditórios?). As Leis Gerais, certamente, tinham um escopo mais reduzido e centrado na administração pública, mas, ainda assim, é possível detectar em sua redação o caráter aberto e antinômico, que se deve mais à expectativa dos juristas e da sociedade diante das leis, do que às especificidades da tradição jurídica ibérica, na qual conviviam diversas fontes de direito autóctones e anteriores ao direito romano ${ }^{16}$. Claro que isto não significa menosprezar a complexa variedade de tradições jurídicas que influenciaram os juristas - a isidoriana, a visigoda, a moçárabe, a civilística, a canonística (BRANCO, 1997, p. 90) -, mas, apenas não identificar nessa amálgama uma falta de pureza e coerência teórica. Se, tal como creem os historiadores, foi a mão de Julião Pais que, em 1211, redigiu as Leis Gerais (VILAR, 2008, p. 195), a dinâmica aberta e complexa do texto manifestaria tanto a formação do mestre como a sua vasta experiência política, construída ao longo de três reinados.

As novidades administrativas e fiscais eram, essencialmente, meios do exercício do poder, e frequentemente significavam tão somente o aumento da complexidade dos instrumentos que podem ser acionados no cenário político, onde se desenvolvia a dinâmica das fidelidades pessoais, e no qual o monarca quer ser um ator com capacidades superiores e incontornáveis. Nesse contexto, é importante sublinhar que as fidelidades pessoais eram o principal motor da política, permitindo, inclusive, o fortalecimento do poder da monarquia. As lógicas e práticas que davam suporte à construção da instituição monárquica não se apoiavam num combate para eliminar as fidelidades pessoais, mas, ao contrário, na sua crescente promoção dentro de um enquadramento e ordenamento

\footnotetext{
${ }^{16}$ Como já referido, o direito romano, independentemente da geografia onde se implantou, sempre conviveu com outras fontes do direito.
} 
que lhe forneciam também bases de legitimidade jurídica. Os discursos que elaboravam a legitimidade eram oriundos de diferentes autoridades, com jurisdições eclesiásticas e laicas, entre as quais, certamente, o rei constituía voz preeminente.

De resto, tanto em Bolonha, como no reino de Portugal, os juristas eram homens de seu tempo, patrocinavam - e/ou inseriam-se em - redes de fidelidades, as quais, por exemplo, se materializavam na capacidade de influenciar diretamente a distribuição de cargos na chancelaria régia, chegando até mesmo a instituir práticas hereditárias dentro da mesma família, como no caso do famoso chanceler Julião ${ }^{17}$. Esses juristas, como bem esclareceu José Mattoso, configuravam um grupo de pressão instalado na cúria régia, com agenda própria e uma clientela e parentela que dependiam da posição que eles ocupavam junto ao rei, além de serem, eles próprios, elos importantes de cadeias que se conectavam a dioceses e mosteiros, a cujos superiores também prestavam fidelidade. A posição de proximidade ao rei era traduzida em benefícios devidamente direcionados a alimentar essas redes, que adquiriam configurações variadas segundo, inclusive, as circunstâncias políticas ${ }^{18}$. Mas, tal como aponta Maria João Branco, identificam-se nessas redes geografias políticas comuns, como o Estudo de Bolonha, a cúria papal, cabidos, bispados, cúria régia. O peso desses juristas era redimensionado pelos contatos que tinham no cenário político português, e se evidenciava pelos laços que ostentavam nas dioceses do reino (BRANCO, 2011, p. 364-365). Portanto, a sublinhar, que o papel dos juristas não pode ser reduzido a apenas um saber técnico e neutro colocado a serviço da monarquia, mas, antes, a um papel cujo sentido só pode ser compreendido historicamente depois de reconstruídas as conexões que atavam esses agentes em cenários mais amplos. Para Hermenegildo Fernandes, eram esses burocratas-juristas, provavelmente, os reais beneficiários da "centralização política”, que defendiam "as regalia com unhas e dentes e procuravam manter uma presença organizada da Coroa”. Eram eles, não o rei, que controlavam a clientela (FERNANDES, 2010, p. 198).

Por outro lado, também a iurisdictio era vivida em causa própria. Quando Vicente Hispano foi acusado pelo bispo de Lisboa, Soeiro Viegas, na cúria romana, de ter abusado de suas prerrogativas no cabido da Sé de Lisboa, este justificava o recurso à justiça do papa pelo fato de mestre Vicente ser protegido do rei e, portanto, não se sentir obrigado a acatar as censuras de seu prelado (VILAR, 2008, p. 275-276). Caso similar é o de Julião Juliães, igualmente acusado de abusar de sua posição de deão da Sé de Coimbra, ao avançar sobre os bens de um cônego,

\footnotetext{
${ }^{17} \mathrm{O}$ chanceler Julião montou uma rede política e familiar, colocando seus membros no serviço da corte e em missões de representação do rei nos foros pontifícios, além de construir bases de atuação e de apoio nas dioceses de Coimbra, Lisboa e Viseu (JORGE et al., 2005, p. 25).

${ }^{18}$ Essa é também a opinião de Bernardo Sá Nogueira, embora acentuando "as fases da vida" dos atores (JORGE et al., 2005, p. 25).
} 
Domingos Eanes, sem que o reclamante conseguisse fazer valer seus direitos, em virtude da proteção régia de que o acusado gozava. Ao recorrer à cúria, o cônego procurava a justiça que não alcançava no reino, mas tampouco conseguia que Julião Juliães atendesse aos apelos do papa, ou mesmo aos seus enviados, para devolver os bens subtraídos ${ }^{19}$. O fato é que ambos, eclesiásticos, valiam-se do foro régio para fugir à jurisdição canônica.

No que se refere à capacidade transformadora que a historiografia costuma atribuir às medidas políticas e administrativas, destacam-se as confirmações régias, ao se entender que o ato jurídico funcionaria como instrumento que criaria uma distância entre o rei e os súditos, demonstrando a superioridade e a soberania régia (FERNANDES, 2010, p. 362). Sem dúvida, o poder de confirmar revela superioridade. Entretanto, a manifestação dessa superioridade, ao contrário do afastamento, revela a aproximação do rei aos súditos ao introduzir o monarca na malha necessária ao reconhecimento da posse de direitos e de jurisdições. Nesse sentido, seria interessante conhecer melhor a lógica que orientava a utilização desse instrumento, pois pela própria historiografia deduz-se que não parece ter servido para eliminar as práticas patrimonialistas da própria monarquia, que continuou distribuindo patrimônio e direitos da coroa entre os súditos merecedores de benefícios. Ao mesmo tempo, tampouco se poderia afirmar que o fato de ter capacidade para distribuir e confirmar mercês garantia ao rei um controle sobre os beneficiados, pois, uma vez mais, os exemplos de “desobediência” apontados pela própria historiografia são muito numerosos.

Ainda sobre o registro de confirmações, Hermínia Vilar entende ser um instrumento de governo precoce e inovador e que não deixa margem a dúvidas quanto ao desejo claro do monarca de controlar privilégios e direitos, talvez com a intenção de criar uma base de informações com as quais cruzar os dados que viria a coletar com as inquirições de 1220. Mas a própria autora reconhece que a intenção se via prejudicada pela ausência do registro de privilégios e direitos das grandes casas da nobreza e até mesmo da maior parte dos domínios eclesiásticos (VILAR, 2008, p. 233-236) ${ }^{20}$. Parece, assim, que é a interpretação historiográfica que cria a inconsistência política, haja vista que em nenhum momento o monarca explicita qual era a intenção de registrar determinados atos jurídicos. Há uma expectativa historiográfica de coerência dos atos régios que é, obviamente, anacrônica.

\footnotetext{
${ }^{19}$ Provavelmente, deve-se a essa questão o forte estremecimento das relações entre o bispo de Coimbra, Pedro Soares, e o rei, pelo fato de aquele ter defendido o cônego (VILAR, 2008, p. 278, 283).

${ }^{20}$ A autora atribui a "inconsistência" da medida à falta de meios e de tempo, uma vez que o monarca faleceria poucos anos depois. Esta circunstância está na base da hipótese de sua obra, cujo subtítulo é "um rei sem tempo". Entretanto, a análise atenta da trajetória política de Afonso II mostra que o rei era "um monarca de seu tempo".
} 
As inquirições são outro instrumento novo importante, e com grande fortuna historiográfica, utilizadas como evidência dos rumos estatalistas da coroa portuguesa, no início do reinado de Afonso II. As inquirições, sobretudo quando interpretadas num contexto político propício à elaboração de medidas jurídicas, não devem causar surpresa, e tampouco ajuda na compreensão do quadro insistir na suposta "precocidade" de Portugal com relação à adoção de estratégias de poder identificadas com o futuro Estado Moderno ${ }^{21}$. As coisas analisadas em contexto mostram por todas as partes uma forte tendência ao registro do patrimônio e dos direitos sobre terras e homens. Não obstante, a maneira muito mais sistematizada, como foi proposta a partir da cúria régia portuguesa, revela apenas a formação acadêmica de seus mentores, que conheciam bem outras experiências de registros desse tipo, oriundas do mundo eclesiástico ${ }^{22}$. O momento político em Portugal, no início do séc. XIII, inspirou a esses juristas uma solução assentada no levantamento de informações que permitissem, antes de tudo, conhecer a situação do rei, do ponto de vista patrimonial e jurídico de fato. Para além da questão financeira - que certamente não era de somenos importância -, a jurisdição régia precisava ser fortalecida. Mas, em virtude da grande fama historiográfica que as inquirições régias portuguesas alcançaram, não seria demais lembrar que o levantamento de informações restringia-se àquilo a que o rei tinha direito. Portanto, não se configurava como "manobra” para aumentar a jurisdição régia sobre as jurisdições dos outros corpos.

As diversas reclamações que se sucederam, interpretadas, pela historiografia em geral, como prova do descontentamento em face do avanço do "projeto de centralização" do poder do rei, são naturalmente provas de descontentamento, mas que provavelmente não traduzem mais do que a insatisfação daqueles que foram colocados publicamente em evidência por supostamente terem desrespeitado a jurisdição alheia. De resto, para dirimir dúvidas de interpretação, é essencial acompanhar o desenrolar jurídico e político dessas inquirições e ver se os desrespeitosos foram punidos, relativamente às usurpações. E, caso tenham sido efetivamente punidos, será indispensável reconstruir a lógica que presidiu a aplicação do instrumento da inquirição. Quanto às inquirições de Afonso II, de 1220, o contexto histórico revela, primeiramente, que, no ambiente em que foram criadas, o rei, em 1218, levara a cabo um número considerável de doações e concessões a bispos e

\footnotetext{
${ }^{21}$ Ver os resultados de um projeto de pesquisa já concluído sobre essa temática em COELHO, 2009, p. 150-154, e em COELHO, 2010, p. 43-54.

22 "[...] a imposição de uma racionalidade nova, cadastral, necessariamente apoiada numa concepção romanista do poder real, que, a não ser do rei, o era pelo menos dos juristas que o cercam [...]” (FERNANDES, 2010, p. 54). Inquirições servem como arma jurídica de parte a parte, tal como se pode comprovar na disputa entre o arcebispo de Braga, Estevão Soares da Silva, e o arcebispo de Toledo, Ximenez de Rada, em torno à primazia da Hispania. Ambos levaram a cabo inquirições em suas respectivas arquidioceses para amparar suas pretensões com testemunhos (VELOSO, 2000, p. 140).
} 
mosteiros, sobretudo dos dízimos régios, o que aponta para uma compreensão do exercício do poder régio muito distante de ilações absolutistas. Em segundo lugar, as inquirições não podem ser separadas de sua motivação política mais evidente: o conflito com o arcebispo de Braga, Estevão Soares da Silva ${ }^{23}$.

As inquirições de 1220 desencadeiam-se após os enfrentamentos com o arcebispo, ocorridos em 1219, depois que este já se tinha refugiado em Roma. O grupo de inquiridores era constituído por clérigos regulares, alguns dos quais conhecidos inimigos do arcebispo, como os priores dos mosteiros de Santa Marinha da Costa e de São Torcato, além de alguns leigos que participaram diretamente nos ataques ao Prelado. Será justamente a região do arcebispado a escolhida para as inquirições. É de ressaltar que, de forma sintomática, os inquiridores interessavam-se exclusivamente pelos direitos que pertenciam ao rei e às ordens regulares, sem se preocuparem com aqueles que poderiam pertencer ao clero secular e a outros senhores laicos. Portanto, não se pretendia criar instrumentos eficientes de governação e de conhecimento do estado do reino, a exemplo do Domesday Book. O rei e sua corte de juristas recorreram aos instrumentos jurídicos e administrativos à disposição para atacar um adversário molesto, como o arcebispo. Sem dúvida, em termos de eficácia política, o fato de ter um grupo de conhecidos adversários do arcebispo circulando e inquirindo em sua diocese, afetando, inclusive, a jurisdição da nobreza que o apoiava, já era suficiente para atingir grandes resultados. Em termos das pretensões da época, dificilmente se esperariam medidas consequentes no sentido de corrigir os abusos ou de punir os abusadores. Em termos concretos, para além das referências truncadas que aparecem nas inquirições, não há qualquer registro que "elucide nem sobre a importância quantitativa ou composição dos rendimentos régios, nem mesmo sobre as formas da sua cobrança ou controle por parte do rei [...]” (VILAR, 2008, p. 252). Ora, é no mínimo estranho que se o objetivo das inquirições fosse o de montar uma base de informações de caráter geral, “com vistas à otimização dos direitos régios e a uma governação mais eficiente”, não se conheçam outras iniciativas de acordo, uma vez que certamente os conselheiros de Afonso II dominavam bem as novidades técnicas.

Os conflitos que configuraram o cenário político português entre os séculos XII e XIII e que permitem conhecer a relação entre a ideia de iurisdictio e a sua experiência estão fundamentalmente registrados nas bulas papais. Quando as partes em confronto se dirigiam a Roma,

\footnotetext{
${ }^{23}$ Ver a opinião de Hermenegildo Fernandes sobre as inquirições, de 1220: "Guardemo-nos, pois, de procurar nessa ação uma consistência ideológica que ela não poderia apresentar, numa sociedade em que a distinção entre o público e o privado estava longe de ter entrado na utensilagem mental dos seus próprios actores [...] e à concepção da monarquia e das regalia não se sobrepõe ainda a do Estado (FERNANDES, 2010, p. 54).
} 
não o faziam na expectativa de uma solução definitiva, mas de uma intermediação que, na forma da voz papal, possuía autoridade reconhecida pelas partes e que serviria como instrumento importante de uma luta que somente poderia se resolver no próprio cenário local. Como se sabe, nem sempre a voz do papa era acatada, embora a historiografia tenha tendência a dar destaque apenas às vitórias pontifícias, o que deforma a imagem que se constrói da capacidade do papa em solucionar $\operatorname{conflitos}^{24}$. De qualquer modo, como referido, é principalmente dos textos das bulas que se recolhem importantes informações sobre lógicas e argumentos adotados por aqueles que participavam ativamente do governo do reino.

Pela bula de Inocêncio III, de 1212, Dilecti filii fratres, dirigida aos bispos de Astorga, Burgos e Segóvia, conhece-se a base da argumentação jurídica do defensor dos interesses de Afonso II na cúria pontifícia, mestre Silvestre Godinho, contra as pretensões da irmã, Mafalda, que tentava fazer valer seus direitos sobre o patrimônio que, em testamento, lhe tinha legado o pai, Sancho I (VELOSO, 2000, p. 76). Mestre Silvestre, de acordo com Maria Teresa Veloso, torcia deliberadamente a qualidade jurídica de Mafalda sobre os domínios do mosteiro de Bouças, ao afirmar que o pai, Sancho I, ter-lhe-ia concedido unicamente o seu usufruto. Entretanto, por meio do próprio texto da doação régia à filha, compreende-se que os termos assentaram-se no "jure hereditario”. Com relação à acusação de que D. Mafalda não havia professado, frustrando as expectativas paternas e, ao mesmo tempo, as cláusulas vinculantes da doação, a autora entende que nisso residiria o único argumento legítimo de mestre Silvestre. Mais adiante, Silvestre Godinho apelava para argumentos que colocam em dúvida a saúde mental do monarca no momento da doação, adotando uma linha de defesa perigosa, na medida em que, ao mesmo tempo, poderia por em dúvida a própria designação de Afonso II como herdeiro, por se tratar do mesmo documento.

Mestre Silvestre recorria, ainda, ao argumento de fidelidade às linhas mestras da concepção jurídica exarada com anterioridade pelo próprio papado, por meio da bula Manifestis probatum, bem como em sua posterior reafirmação. Ele insistia sobre o texto da bula que, em 1183, proibia a diminuição do reino. Para ele, Sancho I, ao distribuir vastas quantidades de patrimônio e direitos entre suas filhas, inviabilizava o reinado do filho, Afonso II. Mas, na concepção corporativa de Sancho I, não se tratava de diminuição, uma vez que as irmãs faziam parte do reino e da própria dinastia régia. Ao mesmo tempo, a tradição hispânica da divisão do reino entre os herdeiros era uma prática política que se entendia de grande utilidade. Mestre Silvestre apela também para outro

\footnotetext{
${ }^{24}$ O bispo de Coimbra queixava-se a Roma sobre a recusa de mestre Vicente em assumir a diocese da Guarda, e que assim via postergada a possibilidade de tentar resolver questões de limites que afetavam a sua diocese. Reclama, ainda, sobre a dificuldade de se executarem as decisões papais sobre as questões em litígio, uma vez que ele próprio contava já com mais de "trinta anos de trabalhos na dita causa, sem receber proveito algum das sentenças já proferidas a seu favor" (COSTA, 1963, p. 161).
} 
trecho da Manifestis probatum, no qual se preveniria sobre a possibilidade de que alguém viesse a perturbar ou prejudicar a integralidade do reino, o que, para o jurista, dever-se-ia interpretar como a proibição papal aos reis portugueses de realizarem doações de território do reino. Maria Teresa Veloso crê que, uma vez mais, o eclesiástico operou um deslocamento no texto da bula que, nesse trecho, deveria ser entendido como referência a possíveis ingerências estrangeiras.

Ainda digno de nota é o fato de mestre Silvestre, na cúria papal, ter usado como linha argumentativa uma fundamentação jurídica que lhe era dada pelas bulas, sem fazer qualquer menção ao direito visigótico que, naquela matéria, teria certamente grande peso (VELOSO, 2000, p. 77). Nesse sentido, destaca-se a escolha de sede de argumentos, orientada pelo tipo de juiz ao qual se submetia a causa. Recorria-se à ideia da superioridade do reino e à soberania, como direito que se sobrepõe àquele manifestado e realizado pelo testamento de um pai que era rei.

Em 1216, Inocêncio III manifestava-se a favor de Afonso II, alegando que no testamento não havia qualquer cláusula que isentasse as irmãs da obediência “à jurisdição régia, pelo que era natural e desejável que as infantas se submetessem ao poder do rei e respeitassem os iura regalia" (BRANCO, 2002, p. 43). Chama atenção que Inocêncio III escolheu como sede de autoridade o próprio testamento de Sancho I, bem como o direito natural. Ainda no que se refere à lógica dos foros, na bula Is qui tangit montes, de 27 de maio de 1211, o papa havia confirmado o testamento de Sancho I, mas absteve-se de confirmar as doações dos mosteiros das infantas, por considerar matéria do foro eclesiástico (COSTA, 1963, p. 29) ${ }^{25}$.

O conflito em torno do testamento teve uma longa história, e somente seria resolvido, pelo menos na aparência jurídica, no início do reinado de Sancho II, por meio de um pacto que o jovem monarca celebrou com as tias. Um pacto que, segundo Hermenegildo Fernandes, embora inspirado pelos seus conselheiros jurídicos, que, reconhecidamente, eram formados dentro dos novos padrões do direito romano, obedecia “ainda” à linguagem feudal. De forma arguta, eles incluíram dispositivos que asseguravam a futura reincorporação do patrimônio e dos direitos correlatos à coroa, o que significava, ao mesmo tempo, o reconhecimento da "preeminência régia”. Entretanto, para o autor, as soluções jurídicas propostas por esses conselheiros não devem ser entendidas como estranhas ou opostas àquela mentalidade, como se constituíssem exemplo da luta do nascente ordenamento estatal e romanista contra o ordenamento feudal, ou como se "a clareza linear da formulação jurídica” tivesse dificuldades em conviver com velhas práticas e com uma estrutura social já ultrapassada (FERNANDES, 2010, p. 128). As estratégias empregadas na redação do documento, muito provavelmente oriundas da experiência jurídica desses conselheiros, mais do que

\footnotetext{
${ }^{25}$ Ou seja, o papa, naquele contexto de “dizer o direito”, não atua como juiz eclesiástico.
} 
revelar conteúdos doutrinais romanistas, mostra um instinto de sobrevivência política que se plasma de maneira eficaz ao conseguir que o partido contrário assinasse um instrumento no qual o rei, para além de ser parte na contenda, passa a ser considerado ponto final do tempo do conflito. A própria trajetória política desses juristas dá mostras de que as ideias trazidas de Bolonha, identificadas com a elaboração abstrata de um rei representante da res publica, conviviam perfeitamente e potencializavam a concepção do dominus rex. Ambas as concepções misturavam-se na experiência política em Portugal, plenas de sentido ${ }^{26}$.

No início do século XIII, o cenário político é também dominado pelo enfrentamento entre os reis e os bispos. Como de costume, aos protagonistas somavam-se atores das mais diversas procedências, misturando vários interesses e objetivos, que, na refrega, ganhavam novos impulsos e configurações. Por exemplo, com relação aos confrontos com os bispos de Coimbra e do Porto, na linha de frente apareciam, além do rei e dos prelados, oficiais e representantes régios, concelhos e clérigos. "O que estava, então, em causa era, mais uma vez, um conflito de jurisdições e de poderes, de privilégios e imunidades de que, nomeadamente, o clero se considerava espoliado por parte do rei e dos seus representantes [...]” (VILAR, 2008, p. 63). Novamente, interessa sublinhar o protagonismo que a jurisdição assume no discurso que traduz e explica os conflitos. As disputas entre os poderosos ganham força por meio do recurso a uma linguagem especializada, com reconhecida autoridade, que reconfigura a aparência e a identidade dos personagens em luta, dandolhes uma dimensão que os eleva acima de suas circunstâncias pessoais. Os confrontos, por meio da linguagem jurisdicional, são, ao mesmo tempo, pessoais e institucionais. A monarquia e o reino, por um lado, a clerezia e a Igreja, por outro, constituem os papéis principais à disposição da aristocracia cristã no teatro político. Entretanto, os interesses que os atores dos conflitos defendem, embora anunciados e legitimados por meio da linguagem jurisdicional, eram fruto das respectivas posições no complicado xadrez político, no qual o laico e o eclesiástico apareciam misturados.

Os exemplos são abundantes, como os dos famosos Martinho Rodrigues, bispo do Porto, e Estevão Soares da Silva, arcebispo de Braga, figuras importantíssimas no reinado de Afonso II (VILAR, 2008, p. 72-75). Esses clérigos, filhos da grande nobreza do reino ligada inicialmente ao monarca, foram posteriormente ferrenhos opositores e justificaram suas ações políticas por meio de um discurso jurisdicional que acusava Afonso II de desrespeitar os direitos da Igreja. A história desse embate não pode ser devidamente dimensionada se Martinho Rodrigues e Estevão Soares da Silva forem considerados apenas como eclesiásticos, omitindo-se as suas ligações com a aristocracia, assim como a liderança política temporal que ambos exerciam.

\footnotetext{
${ }^{26}$ Hermenegildo Fernandes, a este propósito, pensa diferente (FERNANDES, 2010, p. 130).
} 
No enredo de intrigas e confrontos entre a monarquia e os prelados, os conselheiros régios assumiam grande protagonismo. Em 1222, o papa Honório III demonstrava preocupação com relação aos conselheiros que davam suporte jurídico e político a Afonso II, excomungado, recomendando ao monarca que os afastasse da corte. Eram eclesiásticos, cuja grande capacidade intelectual e jurídica os tornava, aos olhos do pontífice, ainda mais perigosos. Tratava-se de mestre Vicente, deão de Lisboa, mestre Julião, deão de Coimbra, e mestre Paio, cantor do Porto. Nesse sentido, a construção do discurso apelava para argumentos cuja eficácia dependia do grau de autoridade daquele que o proferia, o que se refletia, por sua vez, na eficácia das estratégias empregadas para deslegitimar o oponente. Portanto, ao tratar-se de três eclesiásticos, o papa não perdeu a oportunidade de explicitar que, devido justamente à sua condição, a conduta era ainda mais condenável. Tal era o flanco doutrinário mais eficiente e perfeitamente adaptado àquela situação, naquele momento. Alguns anos antes, havia recomendado também o afastamento de dois conselheiros - o chanceler Gonçalo Mendes e o mordomo Pêro Anes da Nóvoa - que exerciam má influência sobre o rei, além de outros eclesiásticos, que seriam responsabilizados por alimentarem o confronto entre Afonso II e o arcebispo de Braga, Estêvão Soares da Silva (BRANCO, 2011, p. 365; VILAR, 2008, p. 247).

Em 1219, as relações entre Afonso II e o arcebispo de Braga entraram num momento crítico, a ponto de Estevão Soares da Silva admoestar publicamente o monarca com relação a seus costumes condenáveis de tomar concubina, vivendo em adultério. Na base das razões do arcebispo, estariam os continuados agravos que o rei impunha à Igreja. Os argumentos do arcebispo, bem aquilatados à causa em questão, colocavam em pauta o comportamento do rei. Tratava-se, obviamente, de um argumento válido do ponto de vista da lógica política, uma vez que a vida íntima do rei, ao tornar-se motivo de escândalo público, passava a engrossar o arsenal de argumentos à disposição na pugna. Os confrontos subiram de tom, e Afonso II mandou atacar os bens do arcebispo em Coimbra e no coração de seus domínios, em Braga (VELOSO, 2000, p. 144).

As informações sobre as violências que ocorriam em Portugal contra a Igreja eram relatadas de viva voz ao papa, pelo arcebispo de Braga, Estevão Soares da Silva, que acabou se refugiando na cúria, depois de ter sido corrido da diocese. Pela bula de 1220, de Honório III, sabese que as queixas do arcebispo contra Afonso II concentravam-se nas decisões do monarca de cobrar indevidamente impostos sobre a Igreja, desrespeitando, inclusive, privilégios e doações régias. Apesar das admoestações do arcebispo, o rei não se corrigira. Ao contrário, desencadeara furioso ataque aos domínios dos eclesiásticos envolvidos no conflito, pelo que, Estêvão Soares da Silva se vira obrigado a excomungá-lo. Na apreciação política e jurídica que Honório III faz do 
caso, na referida bula, a excomunhão atinge igualmente os seus conselheiros mais próximos - o chanceler Gonçalo Mendes e o mordomo Pêro Anes da Nóvoa. Esta valorização do papel dos conselheiros no conflito era, na opinião de Hermínia Vilar, provavelmente fruto da avaliação do próprio arcebispo de Braga. A bula encerra-se com a reiteração da justiça da excomunhão de Afonso II e do interdito do reino, a dispensa dos súditos da obediência ao monarca e a possibilidade de que Portugal pudesse ser anexado por outros reinos cristãos (VILAR, 2008, p. 286-288).

No entendimento do papa, eram os conselheiros, e a maneira como iam configurando o modelo do poder régio em Portugal, a raiz do comportamento do rei. O arcebispo sabia da capacidade política dos conselheiros e conseguiu do papa aquela declaração, cuja abrangência jurídica colocava a descoberto quem governava com o monarca. Para Maria João Branco, estes eram os desafios que se apresentavam a homens como mestre Vicente, que acabavam "apanhados” entre o serviço à Igreja e ao Estado (BRANCO, 2001, p. 519). Entretanto, a situação descrita pelo papado permite ir além das aparências e desdobramentos de uma condição ambivalente, entre o gládio espiritual e o temporal. Embora a tipologia do documento seja pontifícia, portanto eclesiástica, não impede de descobrir nas palavras do papa um conteúdo que revela o lado da contenda política a que ele aderiu. Não se tratava de defender de maneira abstrata princípios jurisdicionais, mas de lançar mão de um discurso que, por meio da autoridade das chaves, pretendia traduzir o emaranhado dos fatos e dar legitimidade à posição do arcebispo. De qualquer forma, não se deve esquecer que, na divisão de campos da contenda, havia eclesiásticos que defendiam as regalia regis de Afonso II contra o arcebispo de Braga, e que, certamente, não se sentiam em posição ambígua ou pensavam que seu apoio jurídico e político ao monarca redundasse em prejuízo da Igreja. Eles eram, ao mesmo tempo, eclesiásticos e conselheiros régios, uma mistura natural na perspectiva daqueles que compunham a aristocracia cristã. Servir à Igreja e à monarquia configurava o papel mais completo a que se poderia aspirar na concepção da respublica christiana.

A realização política do modelo, em suas manifestações conflituosas, não apontava para a inadequação da presença eclesiástica no âmbito do poder, mas para comportamentos inadequados de indivíduos no exercício de suas funções. A participação ativa desses eclesiásticos nas instâncias de poder não era fruto de um "realismo político", que, diante de condições adversas, os obrigava a assumir funções que os afastavam do ideal da Igreja. Decidir se eles estavam do lado da Igreja ou da coroa parece uma questão pouco afeita ao contexto ${ }^{27}$.

O protagonismo que o discurso jurisdicional assume em todas as narrativas não escondia, para os atores políticos, as motivações dos confrontos. O caso do arcebispo de Braga é um exemplo

\footnotetext{
${ }^{27}$ Nesse aspecto, discorda-se de Bernardo Sá Nogueira. Ver NOGUEIRA, 2000, p. 390.
} 
emblemático, uma vez que os fatos ocorridos entre 1219 e 1220 são apenas lances de uma disputa que vinha se desenrolando desde o início do reinado de Afonso II, que envolvia a aristocracia defensora do partido das infantas, que, por sua vez, somava os interesses do rei de Leão, Alfonso IX, à causa (VILAR, 2008, p. 292-296). O recurso às estratégias da gramática jurisdicional garantia, na ótica dos atores, uma legitimidade/ilegitimidade absolutamente necessária para dar autoridade aos seus movimentos. Até mesmo os juristas, considerados como supremas autoridades sobre os princípios que regiam as jurisdições, eram facilmente transformados em atores que atacavam aquilo que “deveriam” defender.

A par da referida bula de junho de 1222, em que reiterava o teor da bula de 1220 , reafirmando a excomunhão do rei, a anuência papal à eventual anexação de Portugal pelos reinos vizinhos, e insistia no afastamento dos conselheiros, Honório III expedia, ao mesmo tempo, uma outra bula, dirigida ao arcebispo de Braga, pela qual autorizava o levantamento da excomunhão, dando a entender que o conflito parecia encaminhar-se para uma resolução.

Em agosto de 1222, o panorama já era completamente diferente, numa demonstração de como os ventos da política mudavam em ritmo vertiginoso. Estêvão Soares da Silva aparecia como confirmante, entre outras importantes lideranças eclesiásticas - portuguesas e leonesas -, de membros da cúria e da nobreza, de uma carta de prestimônio de Afonso II a ninguém menos que mestre Vicente, na qual o rei declarava sua gratidão pelos serviços que este lhe havia prestado. Uma verdadeira folha corrida que mencionava a defesa dos interesses do rei junto ao papa contra as irmãs, as tratativas para o casamento da irmã Mafalda com Henrique de Castela e, finalmente, o empenho nas negociações para o pacto com o arcebispo de Braga (VILAR, 2008, p. 302). Embora historiadores defendam que, obviamente, o rei não chamou todas essas grandes personalidades a Santarém para testemunharem o incensamento de Vicente Hispano, o fato é que não pode passar despercebido que, fosse qual fosse a razão, o momento foi devidamente rentabilizado pelo conselheiro do rei, a ponto de conseguir que o antigo inimigo abrilhantasse com seu nome e posição aquele reconhecimento público de seu desempenho jurídico e político. Quando mestre Vicente foi empossado como chanceler, em 1226, e no intuito de manter as prerrogativas eclesiásticas de que gozava nas sés de Lisboa e de Évora, o papa Honório III concedeu-lhe privilégio, isentando-o da rígida separação que entre as esferas temporal e espiritual estipulava o IV Concílio de Latrão, mormente no que se referia àqueles encarregados da cura das almas. É mais. O papa congratulou o rei pela escolha de um jurista que, para todos os efeitos, era próximo à cúria papal (FERNANDES, 2010, p. 161). 
Entretanto, foi somente no início do reinado de Sancho II que os acordos com o arcebispo de Braga foram devidamente assinados. A composição a que se chegou desdobrou-se em dois documentos. O primeiro, com um caráter que a historiografia entende ser mais doutrinário, uma vez que se insiste nos limites à ação do rei e do arcebispo em matéria espiritual e à necessidade de se restabelecerem os direitos da igreja de Braga, desrespeitados pelo rei anterior. Merece especial destaque a maneira explícita como se afirma o direito da Igreja de “dizer justiça” em seus domínios, quer em assuntos espirituais como temporais, reservando ao rei a possibilidade de o fazer apenas na ausência de juízes da Igreja. O segundo documento, com características judiciais, versava sobre as indenizações que Sancho II deveria pagar ao arcebispo. Na mesma linha do que se disse anteriormente, o pacto não deve ser interpretado como a resolução temporária de duas ideologias em conflito, mas na perspectiva dos interesses das redes de vassalidade e dependência que se reuniram em torno de Afonso II e de Sancho II, por um lado, e do arcebispo, por outro (FERNANDES, 2010, p. 134-135).

Num outro cenário, mas que apresenta a mesma dinâmica, destacam-se as tensões que atravessaram a história da cidade de Lisboa no início do reinado de Sancho II, por meio dos conflitos que envolveram a Sé, o bispo, o concelho, oficiais régios e o próprio monarca. Portanto, Sancho II também herdou, do pai, o conflito com o bispo de Lisboa, Soeiro Viegas. As acusações, padronizadas pelo mesmo roteiro dos conflitos já referidos, em que a Igreja era parte interessada, recaem sobre o desrespeito do monarca aos direitos eclesiásticos, às violências praticadas contra clérigos, à presença de judeus no serviço régio - inclusive atuando em nome do rei em prejuízo da Igreja -, à correção de religiosos acusados de barregania (FERNANDES, 2010, p. 68-69). É interessante notar que o monarca, no discurso que justificava sua atuação na matéria, denunciava o descaminho da conduta moral do clero e a cobrança indevida de taxas aos fiéis, como no caso do bispo Soeiro Viegas e seus adeptos de cobrarem a terça aos moribundos em troca da extrema-unção (FERNANDES, 2010, p. 72). O bispo, que no início do confronto com Vicente Hispano tinha sido apoiado pelo cabido, que reforçava as queixas de Soeiro Viegas contra a forma indevida como o Deão tinha-se apropriado de rendas e direitos da Sé, viu-se, posteriormente, vítima de acusações de alguns cônegos que apoiavam agora o lado do rei (e de mestre Vicente?). Refugiado em Roma, Soeiro aproveitava do clima que as acusações de Estevão Soares da Silva contra Afonso II provocavam para acrescentar as próprias, sempre vinculadas ao desrespeito régio à jurisdição da Igreja (VILAR, 2008, p. 280). Honório III emitia bulas para Portugal, tentando “dizer o direito” do caso, mas sem resultados. Note-se que, apesar do bom trânsito e acurado conhecimento que Vicente Hispano tinha com relação à cúria pontifícia, isso não garantiu a adesão papal à sua causa. Em 
1224, a situação ainda não havia mudado, porque, segundo o queixoso, o rei não mostrava vontade; ao contrário, continuava a se apoderar de direitos da igreja de Lisboa. A lista dos destinatários das missivas pontifícias elucida sobre os apoios poderosos do rei: o abade de Alcobaça e outros priores, como o de Santarém, e religiosos de calibre, como mestre Vicente e mestre Paio (VILAR, 2008, p. 152).

Assim, parece evidente a dificuldade de se sustentar uma explicação que insista sobre a oposição entre o rei e a Igreja. Os interesses de mestre Vicente na matéria não devem ser desprezados, uma vez que ele ainda era deão de Lisboa, e o conflito pessoal que mantinha com o bispo vinha de longa data e, obviamente, continuava vivo ${ }^{28}$. Mas, é ainda importante destacar que as infantas também eram identificadas pelo bispo como inimigas, por terem acobertado o assassino de seu sobrinho e mordomo-mor. A geometria que presidia a composição dos grupos de interesses era muito variável e, num dado momento, podia até mesmo juntar do mesmo lado inimigos históricos, como as infantas e o rei, que acabariam por aparecer lado a lado contra o bispo de Lisboa. Para Honório III, tal como no conflito com o arcebispo de Braga, havia um grupo bem identificado que governava em nome do rei:

[...] o chanceler Gonçalo Mendes, seguido do deão de Lisboa, Mestre Vicente, que seria depois, nesse mesmo ano de 24, ele próprio chanceler, e do chantre do Porto, Mestre Paio. A fechar a lista Pêro Anes da Nóvoa e Henrique Mendes de Sousa. Um fora mordomo até o ano anterior, o outro era-o ainda [...] A importância esmagadora do chanceler não deriva, pois, apenas das qualidades enquanto burocrata, mas também da relevância política que lhe vem de conseguir operar no interior do mundo dos nobres (FERNANDES, 2010, p. 156157).

Vicente Hispano não era um outsider que fez carreira burocrática, mas alguém cujas vinculações de clientela e de parentesco permitiram-lhe ocupar espaços de poder, nos quais pode, por sua vez, montar uma rede própria de apoios que lhe garantiu grande protagonismo político (FERNANDES, 2010, p. 157-158). Pela documentação, Vicente Hispano assume plenamente seu ofício de chanceler durante o cerco de Elvas. A derrota do rei, que se havia associado a Alfonso IX para uma incursão destinada a liberar as praças de Elvas e Badajoz, repercutiu negativamente no entorno do monarca, que foi abandonado por parte do grupo político que lhe dava sustentação. Nesse contexto, sobraram poucos fiéis, e mestre Vicente estava entre eles. Nesse mesmo ano de 1226, mestre Vicente havia sido nomeado bispo da Guarda, dignidade que relutava em aceitar,

\footnotetext{
${ }^{28}$ Vicente Hispano foi acusado por Soeiro Viegas na cúria romana, por ter abusado de suas prerrogativas no cabido da Sé de Lisboa na ausência do bispo, quando este se encontrava engajado no assédio e tomada de Alcácer do Sal. De acordo com o bispo, o recurso à cúria fora motivado pelo fato de Vicente Hispano ser protegido do rei e, portanto, não se sentir obrigado a acatar as censuras de seu prelado (VILAR, 2008, p. 275-276; FERNANDES, 2010, p. 158).
} 
provavelmente devido às poucas atratividades dessa diocese. A destacar que, no ano seguinte, também mestre Silvestre será nomeado arcebispo de Braga (FERNANDES, 2010, p. 196).

O fato é que todos esses casos, que emaranham cenários e atores eclesiásticos e laicos, desenrolam-se com forte protagonismo das armas jurídicas que disparam acusações de cunho jurisdicional. O longo enredo da tramitação de cada um dos embates em Roma sugere uma trama movediça na qual o histórico de cada personagem parecia irrelevante diante das circunstâncias. Na arena política, a tal ponto os poderes laico e eclesiástico aparecem imbricados que ambos os lados esgrimem argumentos de igual cabedal, sendo que a monarquia lança frequentemente mão de argumentos doutrinais do próprio poder papal a seu favor, e vice-versa. No campo da ação, a violência não é monopólio do monarca e amiúde os adeptos da Igreja deram mostras disso. Portanto, no embate entre jurisdições, o próprio discurso é redimensionado e transformado pela experiência, sem obedecer àquilo que hoje se imaginaria “adequado” a um embate ideológico entre poder espiritual e temporal. Os conflitos eram fruto de disputas entre grupos com diversas composições, mas redimensionados politicamente por meio da linguagem do confronto jurisdicional.

Os especialistas nessa linguagem eram os juristas e, tal como o atesta a história que atravessa os reinados dessa época, sua atuação tinha uma eficácia que operava num cenário muito mais amplo do que o de outros atores: “uma elite, um grupo legitimado não apenas pela pertença familiar e pelos laços de parentesco mas pela partilha de percursos comuns e de discursos, por vezes inteligíveis apenas dentro desse grupo [...] que consegue operar a uma escala global” (VILAR, 2008, p. 114).

É indispensável aqui ressaltar que, frequentemente, juristas de renome eram vencidos, o que comprova a indeterminação dos resultados, pelo que a eficácia não deve ser medida com base no cômputo simples de vitórias e derrotas. Da mesma maneira, a coesão entre aqueles que partilhavam percursos intelectuais era permanentemente desfeita pelo curso dos acontecimentos. Mas, sem dúvida, eles tinham a capacidade de dar aos conflitos uma dimensão de grande eficácia política. Por um lado, ao colocá-los em cenários que transcendiam a esfera local, abrindo o leque de soluções e composições. Por outro lado, ao traduzi-los numa linguagem jurídica apropriada à superação da realidade e à sua recriação.

Toda a exemplificação, aqui resumida apenas em brevíssima síntese, aponta para a necessidade de se pôr em questão as sediças propostas que apresentam a lei, as normas e as instituições como simples resultado de causas determinantes, assim como no caso da instituição dos funcionários régios, com suas divisões, atribuições e hierarquias. Igualmente, devem-se interrogar 
as propostas mais recentes, que, no bojo da renovação da história social, dirigiam o foco para a atuação dos funcionários na instituição ${ }^{29}$. No primeiro caso, adotam-se explicações contextualistas que resvalam para interpretações esquemáticas e deterministas, além de se privilegiar a produção doutrinária e programática sobre o corpo do governo, assumindo-a como realidade e totalidade histórica, numa visão idealista e institucionalista. No segundo caso, a tônica recaía sobre as lógicas que embasam as relações sociais da época, e que também pautariam os funcionários do Estado, tornando o estudo do direito praticamente inútil, uma vez que os comportamentos, necessariamente feudais e patrimonialistas, desvirtuariam e corromperiam o plano ideal das instituições, fundando as normas na prática. Neste caso, a abordagem acaba também por promover uma concepção de instituição ideal, ainda que pela via negativa.

Do que acima se expôs, parece razoável concluir que a história da construção da instituição política do poder régio em Portugal manifesta-se, tanto na sua elaboração teórica, quanto na ação de seus atores juristas, colocando-se no mesmo palco e plano as estruturas do poder e a ação dos homens que o exercem e o disputam, em profunda interação. Seguir as estratégias adotadas, as composições e negociações das tramas políticas, permite ao historiador compreender as variáveis que participaram da construção do aparato jurídico, por meio de uma dinâmica que no fraguar dos acontecimentos se abre para diversas possibilidades, sem garantias quanto a desfechos. Tampouco se deve desprezar o fato de que, no transcurso do tempo, essas dinâmicas que se operavam no meio da incerteza lograram se constituir como sede de argumentos de autoridade compartilhados por todos (AUDREN, 1997, p. 567). Pelos conteúdos que se depreendem, quer do texto das normas, quer das narrativas que registram as disputas jurisdicionais, verifica-se uma variedade de argumentos ancorada em referências que misturam, num mesmo patamar, valores religiosos, familiares, políticos, tradições e crenças de diferentes tipos, mostrando a complexidade cultural que alimentava a atuação dos próprios juristas e que, finalmente, são a fonte de legitimidade da norma e dos argumentos escolhidos ${ }^{30}$.

\section{CONCLUSÃO}

Iurisdictio não tem uma definição precisa e estrita. Irnério dizia que é potestas que deve ser permanentemente esclarecida. Tal como a própria ideia de direito, iurisdictio está imersa na temporalidade. A vivência é constitutiva do conceito. A maneira como os homens de leis operavam

\footnotetext{
${ }^{29}$ Ver a crítica que sobre isso se faz, acertadamente, em AUDREN, 1997, p. 560-561.

30 "Un des acquis les plus originaux de la recherche historique récente est d'avoir mis en lumière qu'aucune norme n'est légitime en soi. Cette légitimité est composée, elle est celle des réseaux, des ressources qu'une telle norme mobilise" (AUDREN, 1997, p. 571).
} 
nos cenários políticos decorre de uma cultura política que pressupõe dinâmicas permanentes de interpretação da realidade e dos fatos à luz dos discursos de validade disponíveis, cujos significados são constantemente atualizados no confronto, mediante palavras e argumentos escolhidos para narrar os fatos e classificar os atos, bem como por meio do tipo de instrumentos que os registram. São atores políticos plenos que reúnem numa mesma persona a dimensão laica e eclesiástica, homens da Igreja e do rei. São a encarnação mais perfeita da aristocracia cristã, com apurado sentido do que precisa ser feito e dito para reger a respublica christiana. Ao mesmo tempo, são homens integrados na sociedade, com importante papel na manutenção dos laços de coesão entre os diferentes grupos a que pertencem.

Não é fácil para o historiador seguir de perto e compreender os complexos e “contraditórios” vestígios que a atuação e pensamento desses atores deixaram nos documentos. É verdadeiramente difícil descortinar por entre fórmulas jurídicas, textos doutrinais, etc., os rastros das motivações factuais que inspiraram as escolhas e estratégias que os autores adotaram. Em vista disso, a tendência do historiador é a de olhar para esses documentos de acordo com uma tipologia anacrônica. As leis régias, livros de chancelaria, registros de inquirições e outros similares são encarados por meio das características técnicas de simples racionalidade governamental e administrativa, típicas da nossa contemporaneidade.

Entretanto, cada um desses instrumentos e sua narrativa encerravam uma intenção imersa na ação política e que hoje dificilmente se consegue estabelecer. Ainda nessa perspectiva, parece excessivo atribuir a tais instrumentos objetivos que se confundem com propostas de políticas de Estado impessoais e institucionalistas, mais concretamente, como evidência da tão famosa “centralização precoce” do poder régio em Portugal. Ao contrário, esses instrumentos, que se multiplicam de maneira notável a partir do século XIII, não garantem por si só a implementação de lógicas administrativas impessoais capazes de eliminar as redes patrimonialistas, uma vez que são apenas meios técnicos cujos resultados dependem sempre da cultura política que lhes dá sentido. Neste caso, escusado será dizer que os atores que operavam esses instrumentos orientavam-se por valores que promoviam as lógicas feudais de serviço e benefício. Contudo, isso não impedia que ocorresse a distinção institucional entre as diversas instâncias de poder e de seus respectivos representantes, por meio de um processo que elaborava modelos sociais específicos e estáveis, adaptados aos desafios que a realidade apresentava e aceitos pela sociedade como 'regras do jogo' (AUDREN, 1997, p. 558).

A maneira como o conceito iurisdictio era vivido e experimentado, no seio de uma cultura política que valorizava os laços pessoais e as múltiplas cadeias de obediência e de dependência, 
permitiu que ele fortalecesse as instituições e corpos aos quais dava existência. O estabelecimento dos direitos de cada um deles e o espaço em que se podiam desenvolver eram não somente o resultado de estatutos, privilégios e definições, mas também de sua atuação no tempo, no conflito com outros corpos e instituições, e das sedes de justiça a que podiam ou conseguiam aceder e, obviamente, da sua eventual capacidade de julgar em causa própria.

Quando se analisa de perto o panorama político em que atuaram os juristas e homens de governo, no reino de Portugal, entre os séculos XII e XIII, verifica-se que eram pessoas de seu tempo e que agiam de acordo com as circunstâncias e exigências que suas posições supunham, originadas de diferentes âmbitos que se sobrepunham: família biológica e/ou política, associações, ofícios, laços de vassalagem... A instituição fortalece-se justamente nesse jogo que atravessa a vida e a experiência de seus protagonistas e também pela escolha criteriosa de palavras e argumentos que lhe dão uma identidade específica e, mais importante, circunscrevem seus direitos e liberdades em face dos demais poderes e instituições. Mas tudo isso é principalmente fruto do estreito diálogo entre uma formulação ideal, fundada na concepção de unidade da respublica christiana, e a realidade da instituição, múltipla no tempo.

\section{REFERÊNCIAS}

AUDREN, Frédéric. Les juristes en action : aux origines du droit politique moderne. L'histoire du droit et ses méthodes. Essai d'historiographie. Histoire, économie et société, 16. année, n. 4, 1997.

BRANCO, Maria João. The general laws of Afonso II and his policy of "centralisation”: a reassessment. In: GOSMAN, M.; VANDERJAGT, A.; VEENSTRA (Ed.). The propagation of power in the Medieval West. Groningen: Egbert Forsten, 1997.

. The king's counsellors' two faces: A Portuguese perspective. In: LINEHAN. P.; NELSON, J. (Ed.). The Medieval World. London/New York: Routledge, 2001.

15, 2002.

. Estados, pátrias e nações nos juristas hispânicos dos séculos XII e XIII. Revista Cultura,

. Elites eclesiásticas e perspectivas doutrinárias: do reino à nação (sécs. XII e XIII). In: FERNANDES, H. et al. (Ed.). Nação e Identidades. Portugal, os portugueses e os outros. Lisboa: Caleidoscópio, 2009.

Escritura, ley y poder regio: la cancillería regia y los juristas del rey en la construcción de un nuevo concepto de realeza en Portugal (1211-1218). In: Actas de la XXXVII Semana de Estudios Medievales de Estella: 1212-1214: el trienio que hizo a Europa. Pamplona: Gobierno de Navarra, 2011. 
COELHO, Maria Filomena. A justiça d’além-mar. Lógicas jurídicas feudais em Pernambuco (séc. XVIII). Recife: Ed. Massangana, 2006.

. Monarquia feudal e propaganda política. As inquirições portuguesas como fonte de estudo (séc. XIII). In: II Encontro Regional da Associação Brasileira de Estudos Medievais e I Encontro do Núcleo Dimensões do Medievo (Translatio Studii), 2009, Niterói. Idade Média: abordagens interdisciplinares. Rio de Janeiro: PEM, 2008, p. 150-154.

Inquirições régias medievais portuguesas: problemas de abordagem e historiografia. In: PÉCOUT, Thierry (Org.). Quand gouverner c'est enquêter. Les pratiques politiques de l'enquête princière (Occident, XIIIème-XIVème siècles). Paris: De Boccard, 2010, p. 43-54.

COSTA, António Domingues de Sousa. Mestre Silvestre e Mestre Vicente, juristas da contenda entre Afonso II e suas irmãs. Estudos e Textos da Idade Média e Renascimento. Vol. 1. Braga: Ed. Franciscana, 1963.

COSTA, Pietro. Post fazione. In: COSTA, Pietro. Iurisdictio. Semantica del potere politico nella pubblicistica medievale (1100-1433). Ristampa. Milano: Giuffrè Ed., 2002.

CRESCENZI, Victor. Linguaggio scientifico e terminologia giuridica nei glossatori bolognesi: interpretari, interpretatio. In: WEIJERS, Olga (Ed.). Vocabulaire des écoles et des méthodes d'enseigement au Moyen Âge. Actes du Colloque de Rome, 21-22 de outubro de 1989. Turnhout: Brepols, 1992.

FERNANDES, Hermenegildo. Sancho II. Tragédia. Rio de Mouro: Temas \& Debates, 2010.

GARCÍA Y GARCÍA, Antonio. Iglesia, sociedad y derecho. Salamanca: Universidad Pontificia de Salamanca, 1985.

GROSSI, Paolo. A ordem jurídica medieval. São Paulo: Martins Fontes, 2014.

HESPANHA, António Manuel. As véperas do Leviathan. Instituições e poder político. Portugal século XVII. Coimbra: Almedina, 1994.

IRNERIO. Glosa ad Digestum Vetus, De Iurisdictione. Torino, 1896.

JORGE, A. M. et al. La dimension europèene du clergé de Lisbonne. In: A Igreja e o clero português no contexto europeu. Lisboa: Univ. Católica Portuguesa, 2005, p. 29.

NOGUEIRA, Bernardo de Sá. Igreja Estado. 1. Época Medieval. In: AZEVEDO, Carlos M. de (Dir.). Dicionário de História Religiosa de Portugal. Vol. C-I. Rio de Mouro: Círculo de Leitores, 2000, p. 390.

PORTUGALIAE Monumenta Historica. Leges. Editado por Alexandre Herculano. Vol I. Lisboa, 1856.

VELOSO, Maria Teresa Nobre. Afonso II: relações de Portugal com a Santa Sé durante o seu reinado. Coimbra: Ed. da Universidade, 2000. 
VILAR, Hermínia V. D. Afonso II. O rei sem tempo. Rio de Mouro: Temas \& Debates, 2008.

\title{
BETWEEN BOLOGNA AND PORTUGAL: THE POLITICAL EXPERIENCE OF THE CONCEPT OF IURISDICTIO (XII ${ }^{\mathrm{TH}}$ AND XIII ${ }^{\mathrm{TH}}$ CENTURIES)
}

\begin{abstract}
The act of saying the law (iurisdictio) was the political concreteness in the Middle Ages. The importance of that act in the exercise of power attains some levels as such the theoretical from which we know the thought of the main jurists of that time. Between the XII ${ }^{\text {th }}$ and the XIII ${ }^{\text {th }}$ centuries, Bologna was the center of reference for law studies to which were connected some of the most important names of the recently born kingdom of Portugal. Silvestre Godinho and Vicentius Hispanus are some of the most famous ones that represent those exchanges in the juridical culture domain. In this article we intend to present some problems of research about the intertwining of the concept of iurisdictio issued from Bologna and how it was appropriated/experienced in the Portuguese political scenario.
\end{abstract}

\section{KEYWORDS}

Medieval jurisdiction. Bologna studium. Medieval Portugal. 